\begin{tabular}{|c|c|}
\hline 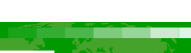 & Malaysian Journal of Social Sciences and Humanities (MJSSH) \\
\hline Malaysian Journal of & Volume 4, Issue 8, December 2019 \\
\hline $\begin{array}{l}\text { (Mumantitis) } \\
\text { (MJ-SSH) }\end{array}$ & e-ISSN : 2504-8562 \\
\hline & $\begin{array}{c}\text { Journal home page: } \\
\text { www.msocialsciences.com }\end{array}$ \\
\hline
\end{tabular}

\title{
Health Empowerment: Health Service Strategies to Poor Community Around Conserved Forest
}

\author{
Muria Herlina ${ }^{1}$ \\ ${ }^{1}$ Department of Social Welfare, Faculty of Social and Political Science, Bengkulu University, Indonesia \\ Correspondence: Muria Herlina (mherlina@unib.ac.id)
}

\begin{abstract}
This research was done in Central Bengkulu District, in suburbs of Semidang Bukit Kabu within conserved forest area. Poverty and isolation were the causes of low access to health services. This weakness requires a strategy through health empowerment. This research purpose was to explore the benefits of community empowerment activities in health as healthy house renovation, doctors visiting to village and free medical treatment and integrated service for elderly by Community Economic Zone (CEZ)-CSR PT. Pertamina. It uses qualitative method to produce descriptive data on public health phenomena related to forests society. There were 11 informants selected by purposive sampling. The data was collected by observation, in-depth interviews and FGD. The research found that informants were elementary school-senior high school students, aged 21-57 years, and came from the Rejang and Serawai tribes, work as coffee plantation farmers, oil palm plantation cultivators and coal vehicle drivers. Their income was IDR 150,000 up to IDR 275,000 per week. The family member were 4-6 person, most of them had semi-permanent and permanent houses, legacy from parent or rent. Diseases often found were hypertension, rheumatic, malaria/typhoid, diabetes, dyspepsia, respiratory diseases, dermatitis, and common cold. The research found that most of them supported the health empowerment program, with various phenomena and meanings from informants. The poor in conserved forest areas need health services through community empowerment in health sector.
\end{abstract}

Keywords: empowerment, health, poverty, conserved forest

\section{Introduction}

The health condition of poor community around conserved forest in Central Bengkulu District needs serious attention to meet health standards such as the use of shaman health services. Most of them do not have BPJS cards, far from health services, bad water facilities and toilets. Suharjito (2017) found that most development only in big cities. Small cities or sub-districts also experience changes with various development activities. However, the edge villages and forest villages are still slightly touched by the development program. Forest villages are generally located far from urban areas with limited road, lighting, clean water, health and education infrastructure. Central Statistics Agency (2014) used a measure of welfare levels with a multidimensional poverty index to include education, health, and living standards. It found that agricultural households classified as multidimensional poor were $21 \%$. At individual level, residents classified as multidimensional poor were $18 \%$. Based on multidimensional measure, proportion of poor agricultural households was 14.6 percent. This shows that household expenditure at edge of forest has not been prioritized for education, health, and living standards. In addition, poor people in Indonesia reached 10.96\% (27.73 million people) with about 
$62.65 \%$ stay at village (BPS, 2015). Weak development in village is characterized by still low availability of basic and economic services, as low availability and accessibility of health services, education, economic facilities and investment, especially villages around the forests.

Health problems can not be solved with by medical and treatment personnel. It needs public health disciplines (Notoatmodjo, 2007). Public health is the science and art to prevent disease, prolonging life and improving health through community organization efforts as, (1) improving environmental sanitation, (2) eradicating infectious diseases, (3) personal hygiene, (4) organizing medical services and care for early diagnosis and treatment and (5) development of social engineering to ensure that every person is fulfilled the needs to maintain his health and overcoming the health problems, especially changing people's behavior for healthy living

Leimena et al. (2012) found that poor people around forest in Mamasa District has several problems, namely: (1) Business Intensity, (2) Knowledge, (3) Skills, (4) Physical and Health Access, (5) Business Capital and (6) Natural Resources and Information Access. The poor community has three types, namely natural poverty, cultural poverty and structural poverty. Soekanto (1982) said that poverty as a condition where a person is unable to take care of himself in accordance with the standard of living of a group and also unable to utilize his mental, or physical energy within group.

The knowledge and skills of each farmer in group will increase the group's social cohesion for the equality and equal feeling. The selection of superior commodities must be adjusted to the conditions of land and community skill to manage. Leading commodities can be developed through social business schemes, both through cooperative organizations or in collaboration with business partners. The success of social business program can support farmers' welfare and forest sustainability. It will give a major contribution to poverty alleviation programs and health for communities around the forest (Dewi, 2018).

\section{Community Empowerment}

Community empowerment is an effort to increase the dignity and status of lower layers of society (grass root) with all the limitations to escape from poverty, ignorance and backwardness. The community empowerment is not only strengthening individuals, but also existing social institutions (Noor, 2011). Choiria et al, 2014) found that Nganjuk forestry sector under Nganjuk Forest Management Unit (KPH) applies welfare program to communities around the forest. In addition to welfare of community around the forest area, Nganjuk KPH also has an important role to preserve the forests in Nganjuk District. Forest Village Community Institution (LMDH) is an institution formed by community around the forest under supervision of Perhutani Nganjuk. LMDH and Perhutani parties worked together to implement this empowerment rightly. LMDH and Perhutani have been made programs to preserve forests and improving community incomes. Adi (2012) examine the empowerment based on Social Development and Empowerment in Social Welfare Science. It can improve the living standard of people, at micro level are individuals, families and groups. Furthermore, development at macro level is used to make changes and empowerment at community and organizational level.

\section{Community Empowerment in Health Sector}

The health empowerment in West Lombok District becomes an embryo to implement the function of healthy areas, namely the Healthy Zone Forum. It created collaboration between social organizations and Health Office to solve health issues and community health empowerment in East and West Lombok District (Paiman et al, 2014). Government makes various efforts to improve maternal and child health. The concept of alert village was used to build a system in a village to maintain the health of community itself, under the guidance and interaction of a midwife and 2 village cadres. In addition, various village officials were also involved in encouraging community participation in health programs such as immunization and Integrated Service (MOH 2006). Standby Village Program was replaced with Birth Planning and Prevention Complications Program (P4K) in 2010 as a government effort to reduce maternal mortality in Indonesia (Kamida, 2018). 
Indonesia created the Sustainable Development Goals in 2016. It was a global action plan for next 15 years (valid from 2016 to 2030) with 17 goals with 169 measurable achievements and targets set by $\mathrm{UN}$ as an agenda the world of development for benefit of humans and earth. It was used to ensure a healthy life and supporting welfare for all human at all ages.

Above phenomenon is very interesting because of a healthy life constraints and welfare support at all ages were difficult to apply for poor Indonesia's population with low access to health facilities, especially the communities around the forest. One support to realize the goals in health sector is community empowerment in health sector, in programs of (1) Healthy Home Renovation, (2) Doctors visiting to the village and free medical treatment and (3) Elderly Village Service. These three activities were formed based on Community Economic Zone activities as a model of Community DevelopmentCorporate Social Responsibility (CSR) of PT. Pertamina's CSR. The target was the poor society with aims to improve people's lives, specifically in health sector (Herlina and Prawito, 2019). The target should be achieved in 2030 to create prosperity and healthy life for poor community. The changes in health status usually require long-term monitoring and cannot be measured during one cycle of program (Haldane et.al, 2019). The complexity of poverty problem also affects on public health. The poor has problem of food, housing, clean water and environmental sanitation (Herlina et.al 2018; Fahrudin 2010).

\section{Health Services}

Health Ministry of Indonesia Republic stipulated in Health Act that health is any effort in an organization to maintain and improve health, prevent and cure diseases and restore health of individuals, families, groups or the community (MOH, 2009). Article 52 paragraph (1) explained that, health services generally consist of two forms of health services. First are Medical health services. It was provided through self care and family care or groups of community members with aim to cure illnesses and restore the health of individuals and families. These individual service efforts were done at health care institutions called hospitals, maternity clinics, and independent practice. Second is Public health services. It was done by groups and communities to maintain and improving health to promote curative and preventive actions. These community service efforts are implemented in certain community health center as Society Service Center.

Law Number 40 of 2004 on National Social Security System (SJSN) and Law Number 24 of 2011 on Social Security Organization Agency (BPJS) stipulate that the health BPJS operation begins on January 1, 2014. The health BPJS organizes a health security program for all Indonesian people to provide the proper public health needs for everyone who has paid contributions (Idris, 2014). Government Regulation No. 27 year 2016 as stipulated in Article 1 stated that Health Service Facility is a tool and / or place used to carry out health service efforts, both promotive, preventive, curative and rehabilitative conducted by central government, regional government, and / or the community. Health Insurance is a guarantee in health protection where participants receive health care benefits and protection in basic health needs provided to everyone who has paid health insurance contributions or health insurance contributions paid by Central Government or Local Government (PerPres RI, 2018).

Communities in urban areas can access the health facilities in complete health facilities both hospitals and clinics, can easily carry out immunizations. Adversely, communities at rural areas have limited facilities to get immunization services and other health services. Indonesian Health Profile in 2010 showed that health were 329,460 units, consisting of 1,632 hospital units, 9,005 health center units, with details of number of health care centers 2,920 units and non-care health centers as many as 6,085 units, supported by supporting health centers of 23,049 units and 318,823 other health facilities consisting of Integrated Service Center and Village Health Center (Nainggolan, et.al, 2016). 


\section{Method}

This research uses a qualitative approach with a case research design to explore the meaning, comprehension, verthehen about a phenomenon, event, or human life that directly or indirectly involved in research setting, contextual and holistic. The meaning exploration during the research process is narrative and holistic (Yusuf, 2016: 328). The reason to use qualitative approach is to find and understand what is the meaning behind phenomena that are sometimes difficult to understand and cannot be explored by statistical or quantitative procedures (Martha and Kresno, $2016: 1$ )

The informants are selected by purposive sampling method, with the conditions of (1) Informants live at around conserved forest for more than 5 years, (2) Can speak Indonesia language, indigenous, (3) willing to provide relevant information to research topic and (4) providing information honestly and with evidence. There were 11 informants in research. The data is collected until saturation answers are obtained from informants. In-depth interviews are used to explore the experiences, opinions and feelings of a variety of people to explore the phenomenon and belief events that consistent with research topic. Focus Group Discussion (FGD) is used to find out views or opinions about health empowerment, in structured and spontaneous conversation. Observation is used to record events and interactions in actual social situations (Spradley, 1980 in Martha and Kresno, 2016: 127)

The research location was Semidang Bukit Kabu forest, known as the Tiger Hill. Land clearing should be done carefully to avoid tigers attack into village. Community plantation activities are only around the slopes of forest.

The data analysis technique is started from reads and analyzes the collected data, data transcription, coding, analysis and matrix formation, content analysis and narrative analysis and conclusions (Martha and Kresno, 2016: 149-171; Neuman, 2016: 559)

\section{Results}

The research was done from June to October 2018. Data was collected from 11 research informants on health empowerment as a health service strategy for poor society at around conserved forests. Table 1 shows the demography of informants based on age, education level, informant's job, income level and their illness.

Table 1: Informants

\begin{tabular}{lcc}
\hline Age & Total & \% \\
21-31 year & 3 & 27,27 \\
32-42 year & 5 & 45,45 \\
43-53 year & 2 & 18,18 \\
54-64 year & 1 & 9,09 \\
Education & & \\
Elementary School & 7 & 63,64 \\
Junior High School & 3 & 27,27 \\
Senior High School & 1 & 9,09 \\
Job & & \\
Coffee Worker & 5 & 45,45 \\
Palm Oil Worker & 4 & 36,36 \\
Mine Driver & 2 & 18,18 \\
Income per week & & $\%$ \\
IDR 150.000 & 4 & 36,36 \\
IDR 200.000 & 5 & 45,45 \\
IDR 275.000 & 2 & 18,18 \\
House Type & & 27,27 \\
Hut & 3 & \\
\hline
\end{tabular}




\begin{tabular}{lcc}
\hline Semi Permanent & 5 & 45,45 \\
Permanen & 2 & 18,18 \\
House Status & & \\
Parents House & 7 & 63,64 \\
Own House & 3 & 27,27 \\
Rent House & 1 & 9,09 \\
Illness & & \\
Hypertension/Rheumatic & 21 & 31,81 \\
/Malaria and Breath Infection & & \\
Diabetes/ Maag & 19 & 28,78 \\
/Itches & & \\
Fever/Cough/Cold & 26 & 39,39 \\
Family Dependent & & \\
4 & 2 & 27,27 \\
5 & 3 & 54.55 \\
6 & 6 & \\
\hline
\end{tabular}

Table 1 above shows that most informants (45.45\%) aged between 32-42 years and the most education is educated elementary school (63.64\%). Most informants work at coffee plantation (45.45\%) with the largest income is IDR 200,000 / week (45.45\%). Most of the house type is semi permanent (45.45) and the status is parent legacy (63.64\%). The frequent illness is Fever/Cough/Cold (39,39\%). The most family dependents are six people (54,55\%).

The matrix for health empowerment program is collected from the informants and related agencies, as shown table 2.

Table 2: Matrix of Health Empowerment Program

\begin{tabular}{|c|c|c|c|c|c|c|c|c|c|c|c|}
\hline \multirow[t]{2}{*}{ Health Empowerment Program } & \multicolumn{11}{|c|}{ Informants Explanation } \\
\hline & 1 & 2 & 3 & 4 & 5 & 6 & 7 & 8 & 9 & 10 & 11 \\
\hline $\begin{array}{l}\text { Health House Renovation (PHBS } \\
\text { Criterion) }\end{array}$ & $\checkmark$ & $\checkmark$ & $\mathrm{x}$ & $\checkmark$ & $\mathrm{x}$ & $\checkmark$ & $\checkmark$ & $\checkmark$ & $\mathrm{x}$ & $\checkmark$ & $\checkmark$ \\
\hline $\begin{array}{l}\text { Doctor Visit to Village and Free } \\
\text { Medicine }\end{array}$ & $\checkmark$ & $\checkmark$ & $\checkmark$ & $x$ & $\checkmark$ & $\checkmark$ & $\mathrm{x}$ & $\checkmark$ & $\checkmark$ & $\checkmark$ & $\checkmark$ \\
\hline Elderly Integrated Service & $\mathrm{x}$ & $\checkmark$ & $\checkmark$ & $\checkmark$ & $\mathrm{x}$ & $\checkmark$ & $\checkmark$ & $\mathrm{x}$ & $\checkmark$ & $\checkmark$ & $\mathrm{x}$ \\
\hline
\end{tabular}

PHBS $=$ Clean and Healthy Life Behavior

Table 2 shows various meanings or information from 11 informants. The program of health house renovation is beneficial for poor at edge of forest because initially the community did not have family toilets and clean water was very difficult, and now the toilets and free clean water are available from village Local Water Companies. There are only 3 people said that the program is less useful to residents with wives busy taking care the house and no longer have time to clean the gardens and the house type is a hut near a bush in forest slope toilet, it is enough to use the river behind the house. Furthermore, they stated that their wife lazy to clean, it is useless to be developed and dirty again.

Doctor program in village and free treatment and medicine are very useful, with two people disagreed because the drug given by doctor did not cure the cough and the body remained thin and other information was confusing because the doctor was still young and "women ". They believe that free medicine was given medicine carelessly and not effective. Nine informants said that programs are very useful for various reasons such as "I feel happy to go to doctor for free, it means there is no need to pay for motorbike petrol because the health Service Center is far from village", "My wife is sick with itching and rheumatic, now she had recover after being given a medicine doctor". The other said "I smoking so many and the cough does not recover, doctor said to stop smoke. I have tried, but can not stop smoking. It make me dizzy and danger me a driver that requires concentration and to reduce drowsiness. 
Elderly Integrated Service Center activities in village are very positive for seven informants. They stated that Elderly Integrated Service Center create enthusiastic live, gathering with other elderly people, were happy together and talked and reminisced while eating porridge or other meals provided by an elderly Integrated Service Center cadre. In addition elderly Integrated Service Center give health information. It makes the grandmothers walk around the house to clean the rooms and beds. Although they still feels embarrassed to exercise, but moving the legs and hands can make sweat and the body become healthier. They want the exercise be held once a month, twice our four times in a month. Together with other can increase the insight and be given food. Integrated Service Center is suitable for elderly health in village. Do not move and lie down makes the body stiff. Meanwhile, some informants did not agree with Elderly Integrated Service Center. They must go with grandmothers or parents to attend Integrated Service Center activities. They said the grandmother was so crunchy to complain that her body had been ill since taking part in exercise and walking to location of elderly Integrated Service Center.

The interviews were done with informants who actively participate in health empowerment activities. Their comments are below.

Our house was chosen for "healthy home renovation" program from Flipmas Rafflesia Besamo. Our house is now walled with planks, tin-roofed and cement-floored. In past the roof was leaking with a wall made from split bamboo with many holes. Today the house had begun to be good, not dirty like before (SA, Lembak tribe, SLTP, 24 years, 25 July 2018).

The hospital is far from here, doctors and village midwives are not on spot every day. They, busy with many problems in Bengkulu. People are kind and friendly, BPJS cards have not been to use. For all I know, Niur Village held an elderly Integrated Service Center every month, the doctor comes there. I often get cough (cold cough) diabetes, weaken and blurred vision (WT, Suku Serawai, SD, 49 years, 21 September 2019).

We feel happy with a doctor enter the village. We can get free treatment and medicine and near from house. At this old age is tired to seek treatment. Sometimes the midwife treated me. Although the doctor does not come at Integrated Service Center, our elderly can eat and stay in touch. (USM, 45 years old; SP, Rejang ethnic group, 71 years old, did not finish elementary school).

\section{Discussion}

\section{Characteristics of Informants}

Majority of informant was is 43-54 years old, elementary school, workers of coffee plantations with average income of IDR 287,500/week, number of dependents of families of 4-6 people, live at huts as legacy from parents. It is consistent with one of informants $(\mathrm{Jk}, 39$ years old, junior high school, tribal Serawai) statement: "My basic income every week is around IDR 200,000, working at coffee plantations, having child 4, not enough to eat for a week, wife should smart to manage the money"

Above information shows that most of informants is categorized in very poor. They do not have a place to live or their own home, the income are not enough to support 6 people in family, their education is low, although within productive age $t$ to work. They do not have other options to work because from cities or districts. This situation is consistent Murti, et. Al. (2017) that in Maesan Subdistrict, Bondowoso District,eEducation and income have a positive and significant effect on income of poor families, the number of family dependents and age have a positive effect on income. It can be interpreted that education, employment and number of dependents affect on poverty, conversely poverty can also be caused by level of education, income and number of family dependents. Nurske (1952) also found a problem in various developing countries or regions. Small capacity real income create low productivity. This becomes larger and resulting in a lack of capital. This conditions because a small saving capacity ... the poor are those who have a per capita income below $50 \%$ of median average income. 
It needs to increase the supply for most poor community groups. It can be done by (1) higher awareness efforts to understand themselves: the potentials, strengths and weaknesses, as well as understanding of their environment, (2) formation and strengthening of institutions, especially institutions at local level, (3) efforts to strengthen policies, and (4) formation and development of business / work networks. The level of empowerment is needed to meet basic needs and mastery and access to various systems and source needed (Susiladiharti, 2002, in Huraerah, 2011).

\section{Health Empowerment}

Table 2 shows that 8 people are happy to hold a healthy house renovation. The selected house becomes clean and neat, has a well water source, has a family toilet, the family has a clean house and health. This condition is supported by Suwarni et al. (2018) that some cases of infants death was caused by diarrheal diseases, acute respiratory infections and tuberculosis, poor environmental sanitation, coverage of exclusive breastfeeding, childbirth by health workers, and clean and healthy living behavior. These are the problem of health sector in the region. The research results show three important things. First, assistance, counselling, and training activities can increase the knowledge / comprehension of community about the importance of clean and healthy living behaviors and raise awareness to start healthy living behaviors. Second, The formation of smart huts and cadres of educators can increase children's interest to read, and help to overcome problems in existing education field. The local government is expected to become a motivator and facilitator for community in an effort to increase community empowerment and increase the potential of village area to increase public health, social and economic in disadvantaged areas. The development of socioeconomic at village needs to be realized to improve the welfare of community that supported by community organizations and participation that continues to grow and develop in people's lives. Principally, community development in any sector contains four elements as the basic framework, namely as a process of change, creating harmonious relationships between needs and resources, capacity building and multidimensional in nature (Almasri et al. 2013).

It was found that 3 informants are not interested to healthy house renovation activities because wife became busy to manage the house, unable to help at fields. The families feel shy because cannot clean the house every day and the children are naughty and are still small. Another reason is limited water, toilet need more water. This behavior is not included in PHBS category. The family will have difficulty TO maintain house cleanliness and environmental pollution. Research results at of Gucialit village shows that several diseases is unhealthy caused by environmental conditions. Many citizens are affected by diseases such as diarrhoea and skin diseases. Diarrhea is associated with polluted environmental conditions, it cause many viruses and bacteria spread. An unhealthy environment due to human waste also causes various skin diseases (Nugraha, 2015).

The community empowerment in health field was done by doctor visit the village for free treatment. Nine informants support this with activity. They do not need to bring the parents and family Society Health Center at a considerable distance with 1.5 hours travelling with two-wheeled vehicles. Doctor visiting to village and free treatment help resident to check the high blood pressure has begun to heal. Patients become aware from diabetes, previously did not know, only treated with Bodrex (meaning the medicine is wrong) dizziness and weakness are thought to heal, wrong medication. Residents are happy for the treatment. Two other informants stated that they were not or unhappy because their wife seek treatment, even though was not sick, just coughing from cigarettes. Another informant said that he was not happy to doctor entered the village and treatment was free, because their brother were not cured, he still felt dizzy, often coughed and body remained thin because of lot smoking, 2 packs a day more. The conditions above are almost the same as research of Karno et. Al. (2017) in Central Java, that health service guarantee model was determined by 13 (thirteen) factors, among the $9^{\text {th }}$ point is human resource information, so clear information and human resources are still limited. The cough treatment caused by smoking is not easy to cure, because the knowledge of citizens / patients about the disease and laboratory tests is lacking, it is assumed once treatment can healed immediately. 
Health Empowerment was done through Elderly Integrated Service Center activities in rural forest outskirts. Elderly means the people with age of 60 years and above. There are many illnesses are felt by elderly. Elderly also need entertainment to gather with fellow seniors to stay in touch with one another to have a spirit for life. There are 7 informants agree with that activities. They give testimony that their mother's have better spirit after participation in elderly Integrated Service Center activities, pain became less. Elderly chat each other. They share many stories of nostalgia and laughter even though among some of them can't hear anymore. Previously could not get up, now I started walking around the house (NI, age 67 years). He was be given green bean porridge or other food provided by village health cadres. While those who did not approve to the program gave reasons that elderly could not come alone, had to be supported / carried, they were busy to accompany their parents to elderly Integrated Service Center. Such conditions are alarming. All family members should be supported and motivate the elderly to take advantage of Integrated Service Center services. Creativity program, handicraft activities, elderly artistic creativity, supplementary feeding, elderly gymnastics, social gathering, regular health checks and other service are done at elderly Integrated Service Center to avoid monotonous. Integrated Service Center cadres and officers must be more active in socializing and succeeding the activities of elderly Integrated Service Center to improve the quality. In addition, families should be able to provide emotional support, accurate information about the benefits of Integrated Service Center for elderly as well as concrete support such as escorting and picking up the elderly to facilitate elderly come to Integrated Service Center (Intarti and Khoria, 2018).

\section{Conclusion}

Better access to health services for society beside forest is highly expected by residents. They generally is classified as poor, so they cannot access the health services provided by government. Health empowerment through healthy house renovations, doctors entering villages and free medical treatment and elderly Integrated Service Center are very beneficial for residents in forest periphery areas. They feel helped by program. For sake of program sustainability, research and community service are focused on activities or studies on health empowerment, health programs are more proactive and very much needed support from relevant stakeholders and various relevant agencies.

\section{References}

Almasri, dan Deswimar D. (2013). Peran Program Pemberdayaan Masyarakat Desa dalam Pembangunan Pedesaan. Universitas Islam Negeri Sultan Syarif Kasim Riau.

Fahrudin Adi (2012). Pengantar Kesejahteraan Sosial, PT. Rafika Aditama, Bandung.

Choiria I, Hanafi I, Rozikin M. 2014. Pemberdayaan Masyarakat Desa Hutan Melalui Lembaga Masyarakat Desa Hutan (LMDH) Sebagai Upaya Meningkatkan Pendapatan Masyarakat (Studi pada LMDH Salam Jatiluhur KPH Nganjuk). Jurnal Administrasi Publik (JAP); 3(12): 2112-7.

Direktorat Jenderal Bina Kesehatan Masyarakat (2009). Program P4K Dalam Rangka Menurunkan AKI. Depkes RI 2009.Jakarta

Dewi IN. 2018. Kemiskinan Masyarakat Sekitar Hutan dan Program Perhutanan Sosial. Info Teknis EBONI: $15(2): 65-77$

Fahrudin Adi (2010). Pemberdayaan, Partisipasi dan Penguatan Kapasitas Masyarakat, PT. Humaniora, Bandung.

Haldane V, Chuah FLH, Srivastava A, Singh R, Koh GCH, et al. 2019. Community participation in health services development, implementation, and evaluation: A systematic review of empowerment, health, community, and process outcomes..PLOS ONE.)

Herlina Muria dan Prawito Priyono (2019). Pemberberdayaan Masyarakat Miskin di Pedesaan Terisolir (dampak kegiatan Kawasan Ekonomi Masyarakat (KEM) Bina Lingkungan CSR PT.Pertamina di Desa Kota Niur Kecamatan Semidang Lagan Kabupaten Bengkulu Tengah, Idea Press Yogyakarta.

Herlina Muria, Prawito Priyono dan Suminar Panji (2018). Strategi Penanggulangan Kemiskinan, PT.Muara Karya (Anggota IKAPI), Surabaya. 
Huraerah Abu (2011). Pengorganisasian \& Pengembangan Masyarakat, Model dan Strategi Pembangunan berbasis kerakyatan, Humaniora, Bandung.

Idris Fachmi (2014). Panduan Praktis Pelayanan Kesehatan, Badan Penyelenggara Jaminan Sosial (BPJS), https://bpjs-kesehatan.go.id/bpjs/dmdocuments/045504ea0d87b5e.pdf

Intarti WD dan Khoria SN. 2018 .Faktor-Faktor yang Mempengaruhi Pemanfaatan Posyandu Lansia. Jhe-S; 2(1): 111-23

Kamida. K ( 2018). Program Perencanaan Persalinan Dan Pencegahan Komplikasi (P4k) Sebagai Upaya Menurunkan Angka Kematian Ibu, Beranda, Vol 16, No 1 (2018) https://www.jurnal.stikes-aisyiyah.ac.id/index.php/gaster/article/view/245

Karno, Adi Rukminto Isbandi, Laksmono Shergi (2017). Analisis Pengaruh Faktor Organisasi Dan Faktor Individu Terhadap Kualitas Pelayanan Puskesmas Studi Pada Puskesmas Kecamatan Kedawung Kabupaten Sragen - Provinsi Jawa Tengah, Jurnal Ilmu Kesejahteraan Sosial Jilid 18, nomor 1, April 2017, 34-47

Leimena, Gany RA, Arsyad M. 2012. Tipologi Kemiskinan Masyarakat yang Bermukim di Dalam dan di Sekitar Kawasan Hutan di Kabupaten Mamasa. Jurusan Perencanaan Dan Kebijakan Pembangunan Pertanian Fakultas Pertanian. Universitas Hasanuddin

Martha Evi dan Kresno Sudarti (2016) Metodologi Penelitian Kualitatif Untuk Bidang Kesehatan, PT.Raja Grafindo Persada, Jakarta.

Mengko VV, Kandou GD, dan Massie RGA. 2015. Pemanfaatan Posyandu Lansia di Wilayah Kerja Puskesmas Teling Atas Manado. JIKMU; 5(2b): 479-90.

Murti Dewa, Fathorraz Moehammad dan Muslihatinningsih Fivien (2017). Faktoryang MempengaruhiPendapatan KeluargaMiskin di KecamatanMaesan, KabupatenBondowoso, eJournalEkonomi Bisnis danAkuntansi, 2017,VolumeIV(2): 182 -186

Neuman W Lawrence (2016) Metode Penelitian Sosial Pendekatan Kualitatif dan Kuantitatif, Edisi 7 , PT Indeks Jakarta.

Nainggolan Olwin , Hapsari Dwi dan Indrawati Lely (2016). Pengaruh Akses ke Fasilitas Kesehatan terhadap Kelengkapan Imunisasi Baduta (Analisis Riskesdas 2013), Media Litbangkes, Vol. 26 No. 1, Maret 2016, $15-28$.

Nugraha Fajar Moh (2015). Dampak Program Sanitasi Total Berbasis Masyarakat (STBM) Pilar Pertama di Desa Gucialit Kecamatan Gucialit Kabupaten Lumajang, Kebijakan dan Manajemen Publik ISSN 2303 - 341X Volume 3, Nomor 2, Mei-Agustus 2015

Nurske Ragnar (1952). Problem of Capital Formation in Underdeveloped Countries, Oxford: Bazil Blacwell

Noor M. (2011) Pemberdayaan Masyarakat. Jurnal Ilmiah CIVIS: I(2).

Notoatmodjo Soekitjo (2007), Promosi Kesehatan dan Ilmu Perilaku, Rineka Cipta, Jakarta

Paiman S. Soemantono, Suhardono (2014). Pemberdayaan Masyarakat di Bidang Kesehatan. Buletin PenelitIan Sistem Kesehatan; 7(1): 1-13.)

Peraturan Presiden Republik Indonesia Nomor 82 Tahun 2018 Tentang Jaminan Kesehatan

Peraturan Pemerintah Republik Indonesia Nomor 47 Tahun 2016 Tentang Fasilitas Pelayanan Kesehatan.

Suharjito Didik (2017). Kesejahteraan Masyarakat Pinggiran Hutan, Dewan Kehutanan Nasional, ttps://indonesiana.tempo.co/read/116700/2017/09/19/suharjito/ diakses 11 Agustus 2018.

Soekanto Soerjono (1982). Sosiologi : Suatu Pengantar, Rajawali Press, Jakarta

Suwarni L, Selviana, Sarwono E, dan Ruhama U. (2018). Pemberdayaan Masyarakat Melalui PENKES (Pendidikan dan Kesehatan) untuk Meningkatkan Derajat Kesehatan Masyarakat. Jurnal Abdimas Mahakam; 2(1).

Undang-Undang Nomor 40 Tahun 2004 tentang Sistem Jaminan Sosial Nasional (SJSN)

Undang-Undang Nomor 24 Tahun 2011 tentang Badan Penyelenggara Jaminan Sosial (BPJS)

Winarwan D. 2011. Kebijakan Pengelolaan Hutan, Kemiskinan Struktural dan Perlawanan Masyarakat. Kawistara; 1(3) : 213-24

Yusuf Muri (2016). Metode Penelitian Kuantitatif, Kualitatif dan Penelitian Gabungan, Prenada Media Group, Jakarta. 